\title{
The Effect of Virtual vs. Traditional Classroom Instruction on Creative Thinking of Iranian High School EFL Learners
}

\author{
Soheila Shafiee Varzaneh ${ }^{1} \&$ Roya Baharlooie ${ }^{1}$ \\ ${ }^{1}$ English Department, Najafabad Branch, Islamic Azad University, Najafabad, Iran \\ Correspondence: Soheila Shafiee Varzaneh, English Department, Najafabad Branch, Islamic Azad University, \\ Najafabad, Iran. E-mail: shafiee648@yahoo.com
}

Received: February 17, 2015 Accepted: March 20, 2015 Online Published: April 23, 2015

doi:10.5539/elt.v8n5p177 URL: http://dx.doi.org/10.5539/elt.v8n5p177

\begin{abstract}
This study investigated the effect of virtual vs. traditional classroominstruction oncreative thinking among Iranian High school EFL Learners. One-hundred and forty three female of high and low level of proficiency, who were selected randomly, were assigned to two VLI $(\mathrm{N}=60)$ and TCI group $(\mathrm{N}=60)$ based on their scores in OPT. Then, each group were divided into two sub groups (high and low level) randomly in order to evaluate the effect of proficiency of each group on creative thinking. At first, a pre-test of creative thinking was administered for both groups to identify the amount of creative thinking. Then participants of both groups received 14-sessions same language learning English book1 but virtual group taking advantage of weblog while the participants of traditional group learned language in traditional environment. At last, all learners of the study were given a creative thinking test as post-test. Also, this test was administered on sub groups separately. Researcher used a pretest-posttest of Gilford (1976) for measuringlevel of creative thinking of learners. In addition, attitudesquestionnaire on different learning situation (Till, 2004) was used to evaluate attitudes of both VLI and TCI groups. T-test was used to analyze the data, which revealed that total gain in creative thinking domain by VLI and also high VLI subgroups was significantly superior to the total gain in creative thinking domain by other groups. Also, the attitudes of the VLI group participants were also higher than the TCI group participants. The findings of the study can be used as guidelines for designing classroom environments that can improve the creativity of learners.
\end{abstract}

Keywords: traditional classroom, creative thinking, virtual classroom, attitude, instruction

\section{Introduction}

Thinking is an undeniable part of human's life. Everyone thinks and as the result what people do, depends on the quality of their thoughts. So, when someone is told and forced to reach to a decision about something new, thinking deeply is required and asking how and why, are the first steps of making a good decision process. It's about how one presents himself as an important person who enjoys teaching his subject; how he stimulates his learners to contribute; how he goes about making learning more enjoying or interesting. Paul (2003) asserted that thinking intellectually refers to the teaching practice andvision of Socrates 2500 years ago who discovered that people could not rationallyjustify their confident claims to knowledge. He established the importance of asking deep questions that probe profoundly into thinking before we accept ideas. His method of questioning is now known as "Socratic Questioning" and is the best known creative thinking teaching strategy.

Although creativity is a God gift but it can be developed through the use of creative thinking approaches. Creative thinking helps the learner to use thoughts in its various proportions. It can be defined in two ways: 1) Teaching creatively 2) Teaching for creativity (Maleki, 2000). Moreover, due to technical progress and globalization, the modern civilization undergoes deep and fast changes. This fact creates new problems that the individuals are confronted with and in order to contract with these harms one wants a well-developed ability to adapt to new situations like virtual learning and to find new ways to do things. In this background, the use of different learning environments on creative thinking proves to be a very significant reserve that might help persons to contract in an improved way with communal and technological changes. Although a large body of work exists to the use of creative thinking approaches in teaching process in the developing countries but in thecountries like Iran, it is an essential stage particularly in the field of teaching foreign languages i.e. English language. Further, a very few research studies have been conducted for developing material for self-learning 
techniques in teaching language situation. Using creative thinking approaches based on creative thinking material in teaching language can help to meet the challenges of teaching English language in Iran schools.

\section{Literature Review}

Though both traditional academic and virtual learning processes have notably converged in the past decade, they still can be differentiated. Prensky (2000) stated that these days for learners, world without computers, digital media or the internet is meaningless. He observed the world of information and communication technology in a different way in comparison with the adults in their life, who in contrast, were viewed digital immigrants.

According to Szendeffy (2005), much research has been focused on the effectiveness of VLI, which is demonstrated through improved test scores. Effectiveness has also been measured through heightened affective responses, or better attitudes, reduced learning time, higher course completion rates, increased retention duration, and finally cost (p. 214).

Cotton (2001) claimed that the use of VLI leads to more positive student attitudes than the use of conventional instruction. This general finding has emerged from studies of the effects of VLI on student attitudes.

Cotton (2003) stated that Virtual learning instruction (VLI) could be of great help because of the drill-and-practice, tutorial, or simulation activities offered either by themselves or as supplements to traditional teacher directed instruction.

According to Mayer (2007), the theoretical rationale behind the multimedia principle is that when both words and pictures are presented, learners are able to establish verbal and pictorial mental models and build effective connections between them.

A further elaboration by Smith (2007) distinguished the spontaneous interaction of thetraditional classroom from the extensive pre-preparation required bydistance-learning formats. He identified advantages and disadvantages ofvirtual learning, summarizing that virtual learning could be both highly interactive and simultaneously isolating because of the inherent difficulties of developing cohesiveness and true connectedness among learners. Similarly, Sauer (2005) described virtual learning as adjusting to rapidobsolescence and requiring just-in-time training of transitory knowledge adaptable to a specific venue, as opposed to more stable and durable academic processes.

The conclusion of all thesestudies indicated that close student-teacher relationships, student choice in assigned work, a de-emphasis on grading and explicit instructions in creativity supported studentcreative performance. It also emphasized that learners need to feel safe and able to take risks in order to do creative work.

\section{Objectives of the Study}

The study paid more attention to the application of VCI as a new method of teaching intechnological age on creative thinking performed by Iranian EFL learners and then compared it with that performed in TCI group to see the similarities and differences between the groups. The purpose of the present study was twofold: to determine the effect of VCI and TCI on creative thinking of Iranian EFL learners and also, to explore the attitudes of VCI and TCI groups on different situations about learning situation.

\section{Research Questions}

This article was designed to seek answers to the following questions:

RQ1. Is there any significant difference between VCI and TCI groups in terms of the development of creative thinking among Iranian high school EFL learners?

RQ2. Does proficiency level make a difference between VLI and TCI groups in terms of the development of creative thinking among Iranian high school EFL learners?

RQ3. Is there any significant difference between the attitudes of VCI and TCI groups of Iranian high school EFL learners toward learning situation?

\section{Methodology}

\subsection{Participants}

The participants of this study were 120 out of 143 female EFL high schools learners from five different high schools located in Esfahan, Iran. The mean age of the sample was ranging from 15 to 16. They studied English book 1, which is an obligatory two credit course for first year learners. The participants were selected randomly. The native language of learners was Persian and English was their second language. None of the learners studied English abroad. The participants were divided into two high and low groups based on their scores on OPT (+/- 
2SD).

\subsection{Instruments}

Four instruments were employed: 1) 60-item oxford placement test (OPT), and 2) Weblog is a multimedia-integrated virtual learning systemdeveloped for this research. It was used as a virtual classroom that both teacher and learners can share their learning needs or anything that is not possible through normal class time, 3) the main instrument used for measuring creative thinking Developed by Gilford that the researcher measured the creativity of each learner through divergent thinking (the Gilford Test of Creative Thinking) The end product is assessment on originality, fluency, flexibility, and elaboration (Gilford, 1967). 4) The attitudes of students on different learning situation, and perceived learner satisfaction measured with Dundee questionnaire (Dundee, 1997).

\subsection{Data Collection}

According to Hayward (2007) homogeneous grouping helps to minimize variability in work efficiency and resulting boredom and off-task behavior that can be expected some individuals finish with a given part of the task well before others do. So in order to make sampling fairly homogenous in terms of their level of proficiency, at the first session Oxford Placement Test (OPT) was administered. The VLI group used the weblog system as the virtual learning environment for testing hypotheses. They were enrolled in the online course English book 1, at the high school of Esfahan during autumn semester 2014. The TCI group enrolled in the same course but in traditional classroom. The classes were held three days a week for 14 sessions and each session was 90 minutes. At the second session for 10 minutes all learners tookthe standardized Gilford test of measurement aspretest, after pretest, each lesson was taught in ninety minutes. The learning outcome was measured by the difference between individual pre- and at least in post-test. After the test, each participant was required to fill out a questionnaire to assess her perceived satisfaction and to give feedback on the educational system and their learning experience. Data was collected with a guided self-administered questionnaire during a face-to-face session. The System had been designed and implemented with an easy-to-use interface and no participant reported any difficulty in using it.

1) Pre-test: Subjects took the standardized Gilford test of measurement of creative thinking.

2) Online and traditional classroom session: After all participants understood how the system worked and both groups become familiar with the process of action, both groups were given 20 minutes to become familiar with the context. This gave participants extra time to review the learning material and practice based on them. Each participant was given the PowerPoint slides at the beginning of each session. At the end of each session, participants were given written exam, consisting of objective questions (with standard answers) about the lecture.

3) Post-test and attitude questionnaire: The test types in the post-test were similar to those in the pre-test. In addition, all learners took an attitude questionnaire to evaluate the attitudes of learners regarding to different context.

\subsection{Data Analysis}

In order to see whether there were similarities or differences across the four groups, in the amount of creative thinking on VLI and TLI groups, the quantitative analyses were conducted. To answer research questions, three types of analysis were carried out on the collected data. The present data were interval in nature and none of the subjects participated in more than one group. The analysis of the results was done by the researcher. Scoring of creative thinking test is comprised of four components:

- Originality: how uncommon uses are (e.g. "Imitation mini-trombone" Is more uncommon than "holding papers together" for the word "paper clip"). Responses that were given by only $5 \%$ of group are unusual (1 point), responses that are given by only $1 \%$ of group are unique ( 2 points).

- Fluency: total. How many uses the learner can come up with. Score is just number of all the responses.

- Flexibility: different categories. How many areas answers cover (e.g. cufflinks and earrings are both accessories, but in one area). One point is given to each area.

- Elaboration: level of detail in responses; "keeping headphones from getting tangled up" 2 point whereas "bookmark" 1 point, two for further detail.

The third question focused on the attitudes on different learning situations. Data was analyzed byStatistical Package for Social Sciences (SPSS) version 22. So, the data analysis based on the results ofquestionnaire was done. 


\section{Results}

The first instrument of this study was OPT. It was administered at the first session and 143 learners participated in this test. Then, those learners whose scores were 2SD above the mean were classified as high and those whose scores were 2SD below the mean were classified as low group. 10 participants were deleted from the sample because their scores had a great differences with others' scores or they were absent during some treatment sessions. To do random sampling of subjects, the learners in each group (low/high) had a number from 1 to 60 . Odd numbers were assigned to VLI group and even numbers were assigned to TCI group. Table 1 shows the results of OPT. The meanscore of OPT was $39.40(\mathrm{SD}=10.14)$.

Table 1. OPT results

\begin{tabular}{llllll}
\hline & $\mathrm{N}$ & Minimum & Maximum & Mean & Std. Deviation \\
\hline OPT & 120 & 15 & 59 & 39.40 & 10.14 \\
\hline
\end{tabular}

\subsection{The Effect of VLI and TCI on Creative Thinking}

In order to make sure that there was nostatistically significant difference between VLI and TCI groups at the beginning of the study, an independent sample t-test was used. Table 2 shows the results of this test.

Table 2. Independent sample t-test

\begin{tabular}{lllllll}
\hline & $\mathrm{N}$ & Mean Difference & Std. Deviation & $\mathrm{df}$ & $\mathrm{p}$ & $\mathrm{t}$ \\
\hline VLI & 60 & 41.20 & 9050 & 59 & .00 & 33.57 \\
TCI & 60 & 37.61 & 10.75 & 59 & .00 & 27.08 \\
\hline
\end{tabular}

As presented in Table 2, the results of the t-test indicated that there was no significant difference between the mean score of the two groups at the beginning of the study $(\mathrm{P}>0.05)$. So VLI and TCI groups did not differ significantly before mediation.

In this study there were one question in Gilford's Alternative Uses Task for both pretest and posttest. In the area of different condition, a significant difference in pretest to posttest scores in interpreted as creative thinking.

The first research question was concerned with the difference between VLI and TCI groups in creative thinking, two sub-questions had to be addressed:

1) Sub-question1: the difference between VLI and TCI in the pre test

2) Sub question2: the difference between VLI and TCI in the post test

To answer the first sub-question, a comparison between VLI and TCI scores indicates that the learners in TCI group outperformed the other group in pre-test. As Table 3 shows the mean score of TCI group in $64.01(\mathrm{SD}=$ $10.28)$ but the mean score of VLI group is $62.85(\mathrm{SD}=10.65)$.

Table 3. Pretest results

\begin{tabular}{lllllll}
\hline Variables & Pretest groups & $\mathrm{N}$ & Maximum & Minimum & Mean & Std. \\
\hline \multirow{2}{*}{ Originality } & VLI & 60 & 24 & 14 & 19.15 & 3.01 \\
& TCI & 60 & 24 & 16 & 19.97 & 2.44 \\
\multirow{5}{*}{ Flexibility } & VLI & 60 & 17 & 8 & 12.22 & 2.66 \\
& TCI & 60 & 16 & 8 & 11.70 & 2.67 \\
Elaboration & VLI & 60 & 13 & 7 & 9.38 & 1.72 \\
& TCI & 60 & 15 & 7 & 11.41 & 2.45 \\
\multirow{5}{*}{ Fluency } & VLI & 60 & 28 & 18 & 22.10 & 3.26 \\
& TCI & 60 & 26 & 17 & 20.93 & 2.72 \\
& CLI & 60 & 82 & 47 & 62.85 & 10.65 \\
& TCI & 60 & 81 & 48 & 64.01 & 10.28 \\
\hline
\end{tabular}


For answering the second sub-question needs a look at Table 4, which shows the scores of VLI and TCI groups in posttest. As it is shown, the VLI group significantly outperformed TCI group. The mean score of VLI is 94.82, which is higher than its mean score in pretest (63.06). Although the mean score of TCI in posttest was 67.53, it did not greatly change in comparison to its mean score in pretest (65.41).

Table 4. Posttest results

\begin{tabular}{lllllll}
\hline Variables & Groups & $\mathrm{N}$ & Maximum & Minimum & Mean & Std. Deviation \\
\hline \multirow{2}{*}{ Originality } & VLI & 60 & 31 & 20 & 25.98 & 2.93 \\
& TCI & 60 & 24 & 14 & 19.60 & 2.75 \\
& VLI & 60 & 21 & 14 & 17.77 & 2.15 \\
\multirow{5}{*}{ Elabibility } & TCI & 60 & 17 & 8 & 13.30 & 2.53 \\
& VLI & 60 & 20 & 14 & 16.65 & 2.01 \\
\multirow{5}{*}{ Fluency } & TCI & 60 & 16 & 10 & 13.53 & 1.75 \\
& VLI & 60 & 41 & 28 & 35.47 & 4.22 \\
& TCI & 60 & 31 & 18 & 25.17 & 3.90 \\
& VLI & 60 & 106 & 82 & 94.82 & 6.53 \\
& TCI & 60 & 79 & 61 & 67.53 & 4.82 \\
\hline
\end{tabular}

Table 5 shows a comparison between the groups in their pre- and posttest scores based on a paired sample t-test. As Table 5 shows for VLI groups, T value for creativity was 22.03 and df was 59 . The mean difference in the two scores was 32.90 with a 95 percent confidence interval stretching from a lower bound of 35.60 to an upper bound of 28.30 .

For TCI groups, T value for creativity was 7.20 and df was 59. The mean difference in the two scores was 7.79 with a 95 percent confidence interval stretching from a lower bound of 10.60 to an upper bound of 5.90. As the analysis of data in pretest and posttest in both VLI and TCI groups showed, VLI group significantly outperformed TCI group in posttest. But there are no significance differences between flexibility and originality in TCI groups $(p>0.05)$. In others variables there is significance differences between two group $(p<0.05)$.

Table 5. Paired samples test for both groups in pre- and post-test

\begin{tabular}{|c|c|c|c|c|c|c|c|c|c|c|}
\hline & & & \multicolumn{5}{|c|}{ Paired Differences } & \multirow{3}{*}{$\mathrm{t}$} & \multirow{3}{*}{ df } & \multirow{3}{*}{$\begin{array}{l}\text { Sig. } \\
\text { (2tailed) }\end{array}$} \\
\hline & & & \multirow[t]{2}{*}{ Mean } & \multirow{2}{*}{$\begin{array}{l}\text { Std. } \\
\text { Deviation }\end{array}$} & \multirow{2}{*}{$\begin{array}{l}\text { Std. Error } \\
\text { Mean }\end{array}$} & \multicolumn{2}{|c|}{$\begin{array}{l}95 \% \text { Confidence Interval } \\
\text { of the Difference }\end{array}$} & & & \\
\hline & & & & & & Lower & Upper & & & \\
\hline \multirow{5}{*}{ Pair 1} & \multirow{5}{*}{$\begin{array}{l}\text { Pretest VLI- } \\
\text { posttest VLI }\end{array}$} & Originality & 6.83 & 4.12 & .53 & 7.89 & 5.76 & 12.82 & 59 & .00 \\
\hline & & Flexibility & 5.55 & 3.41 & .44 & 6.43 & 4.66 & 12.58 & 59 & .00 \\
\hline & & Elaboration & 7.26 & 2.57 & .33 & 7.93 & 6.60 & 21.90 & 59 & .00 \\
\hline & & Fluency & 13.36 & 4.14 & .53 & 14.43 & 12.29 & 25.00 & 59 & .00 \\
\hline & & Creativity & 32.90 & 13.24 & 1.70 & 35.60 & 28.30 & 22.03 & 59 & .00 \\
\hline \multirow{5}{*}{ Pair 2} & \multirow{5}{*}{$\begin{array}{l}\text { Pretest } \\
\text { TCI-posttest } \\
\text { TCI }\end{array}$} & Originality & .36 & 3.50 & .45 & .53 & 1.27 & .81 & 59 & .42 \\
\hline & & Flexibility & 1.60 & 4.60 & .59 & 2.78 & .41 & 2.69 & 59 & .00 \\
\hline & & Elaboration & 2.16 & 2.63 & 0.03 & 2.85 & 1.48 & 6.32 & 58 & .00 \\
\hline & & Fluency & 4.23 & 5.29 & 0.68 & 5.60 & 2.86 & 6.19 & 59 & .00 \\
\hline & & Creativity & 7.79 & 15.86 & 1.70 & 10.60 & 5.90 & 7.20 & 59 & .00 \\
\hline
\end{tabular}

Therefore, the first hypothesis was rejected because the female learners in VLI and TCI groups were different in different situations.

\subsection{The Effect of Proficiency on Creative Thinking between VLI and TCI Groups}

The second research question was concerned with the differences between VLI and TCI groups in different 
proficiency levels, four sub-questions had to be addressed:

1) Sub-question1: the difference between high VLI and TCI groups in the pretest

2) Sub-question 2: the difference between low VLI and TCI groups in the pretest

3) Sub-question 3: the difference between high VLI and TCI groups in the posttest

4) Sub-question 4: the difference between low VLI and TCI groups in the posttest

The first sub-question seeks to see whether there is a difference between high VLI and TCI groups in the pretest or not. To answer this question the mean scores of these two groups were compared. As Table 6 shows the mean score of creativity for high VLI groups in pretest was $72.65(\mathrm{SD}=5.42)$ ranging from 61 to 81.

Table 6. Pretest results of high group

\begin{tabular}{lllllllll}
\hline & $\begin{array}{l}\text { Assessment } \\
\text { technique }\end{array}$ & Level & Variables & $\mathrm{N}$ & Minimum & Maximum & Mean & $\begin{array}{l}\text { Std. } \\
\text { Deviation }\end{array}$ \\
\hline \multirow{6}{*}{ Pretest } & VLI & High & Originality & 30 & 20.00 & 24.00 & 22.06 & 1.48 \\
& VLI & High & Flexibility & 30 & 10.00 & 17.00 & 13.33 & 2.13 \\
& VLI & High & Elaboration & 30 & 12.00 & 15.00 & 13.36 & .85 \\
& VLI & High & Fluency & 30 & 20.00 & 26.00 & 24.93 & 1.98 \\
& VLI & High & Creativity & 30 & 61.00 & 81.00 & 72.65 & 5.42 \\
\hline \multirow{5}{*}{ Pretest } & TCI & High & Originality & 30 & 15.00 & 24.00 & 19.06 & 2.43 \\
& TCI & High & Flexibility & 30 & 10.00 & 17.00 & 13.63 & 2.31 \\
& TCI & High & Elaboration & 30 & 11.00 & 16.00 & 13.96 & 1.24 \\
& TCI & High & Fluency & 30 & 20.00 & 23.00 & 22.96 & 1.90 \\
& TCI & High & Creativity & 30 & 55.00 & 79.00 & 69.50 & 6.30 \\
\hline
\end{tabular}

The second sub-question is a way to see the difference between low VLI and TCI in pretest. Table 7 shows the mean score of low VLI group for creativity was 56.05 ( $\mathrm{SD}=5.30)$ ranging from 48 to 65 but the mean score of low TCI group for creativity was $65.98(\mathrm{SD}=10.20)$ ranging from 49 to 81 .

Table 7. Pretest results of low groups

\begin{tabular}{lllllllll}
\hline & $\begin{array}{l}\text { Assessment } \\
\text { technique }\end{array}$ & Level & Variables & $\mathrm{N}$ & Minimum & Maximum & Mean & $\begin{array}{l}\text { Std. } \\
\text { Deviation }\end{array}$ \\
\hline \multirow{5}{*}{ Pretest } & VLI & Low & Originality & 30 & 16 & 19 & 17.87 & .93 \\
& VLI & Low & Flexibility & 30 & 8 & 15 & 10.07 & 2.10 \\
& VLI & Low & Elaboration & 30 & 7 & 12 & 9.47 & 1.87 \\
& VLI & Low & Fluency & 30 & 17 & 20 & 18.67 & 1.02 \\
& VLI & Low & Creativity & 30 & 48 & 65 & 56.05 & 5.30 \\
\hline \multirow{3}{*}{ Pretest } & TCI & Low & Originality & 30 & 14 & 24 & 19.90 & 3.17 \\
& TCI & Low & Flexibility & 30 & 8 & 17 & 12.83 & 2.91 \\
& TCI & Low & Elaboration & 30 & 10 & 16 & 12.76 & 2.06 \\
& TCI & Low & Fluency & 30 & 18 & 25 & 21.50 & 2.56 \\
& TCI & Low & Creativity & 30 & 49 & 81 & 65.98 & 10.20 \\
\hline
\end{tabular}

The third sub-question seeks to see whether there is a relationship between high VLI and TCI groups in the posttest or not. Table 8 shows descriptive statisticsin high group in posttest. 
Table 8. Posttest results of high group

\begin{tabular}{lllllllll}
\hline & $\begin{array}{l}\text { Assessment } \\
\text { technique }\end{array}$ & Level & Variables & $\mathrm{N}$ & Minimum & Maximum & Mean & $\begin{array}{l}\text { Std. } \\
\text { Deviation }\end{array}$ \\
\hline \multirow{6}{*}{ Posttest } & VLI & High & Originality & 30 & 26.00 & 31.00 & 28.33 & 1.66 \\
& VLI & High & Flexibility & 30 & 14.00 & 20.00 & 18.36 & 1.84 \\
& VLI & High & Elaboration & 30 & 14.00 & 20.00 & 17.00 & 2.13 \\
& VLI & High & Fluency & 30 & 28.00 & 41.00 & 35.86 & 4.08 \\
& VLI & High & Creativity & 30 & 81 & 112 & 98.52 & 9.60 \\
\hline \multirow{5}{*}{ Posttest } & TCI & High & Originality & 30 & 20.00 & 24.00 & 21.66 & 1.37 \\
& TCI & High & Flexibility & 30 & 12.00 & 17.00 & 14.50 & 1.59 \\
& TCI & High & Elaboration & 30 & 9.00 & 12.00 & 10.80 & 1.03 \\
& TCI & High & Fluency & 30 & 21.00 & 28.00 & 24.93 & 1.72 \\
& TCI & High & Creativity & 30 & 62 & 81 & 70.68 & 4.60 \\
\hline
\end{tabular}

The comparison between these two groups shows high VLI significantly outperformed high TCI group in posttest.

The fourth sub-question seeks to see whether there is a relationship between low VLI and TCI groups in posttest or not. Table 9 shows descriptive statistics of low groups in posttest. As Table 9 shows the mean score of low VLI group in creativity was $91.10(\mathrm{SD}=9.35)$ ranging from 76 to 108 , the mean score of low VLI group in creativity was $52.65(\mathrm{SD}=3.85)$ ranging from 46 to 62 .

Table 9. Posttest results of low groups

\begin{tabular}{lllllllll}
\hline & $\begin{array}{l}\text { Assessment } \\
\text { technique }\end{array}$ & Level & Variables & $\mathrm{N}$ & Minimum & Maximum & Mean & $\begin{array}{l}\text { Std. } \\
\text { Deviation }\end{array}$ \\
\hline \multirow{6}{*}{ Pretest } & VLI & Low & Originality & 30 & 20 & 26 & 23.63 & 1.82 \\
& VLI & Low & Flexibility & 30 & 14 & 21 & 17.17 & 2.29 \\
& VLI & Low & Elaboration & 30 & 14 & 20 & 16.30 & 1.86 \\
& VLI & Low & Fluency & 30 & 28 & 41 & 35.07 & 4.40 \\
& VLI & Low & Creativity & 30 & 76 & 108 & 91.10 & 9.35 \\
\hline \multirow{5}{*}{ Pretest } & TCI & Low & Originality & 30 & 14 & 20 & 16.63 & 1.88 \\
& TCI & Low & Flexibility & 30 & 8 & 12 & 10.00 & 1.20 \\
& TCI & Low & Elaboration & 30 & 7 & 9 & 7.93 & .74 \\
& TCI & Low & Fluency & 30 & 17 & 21 & 19.13 & 1.16 \\
& TCI & Low & Creativity & 30 & 46 & 62 & 52.65 & 3.85 \\
\hline
\end{tabular}

Table 10 shows a paired sample t-tests for every pair of groups. 
Table 10. Paired samples t-test for different proficiency levels in pre- and post-test

\begin{tabular}{|c|c|c|c|c|c|c|c|c|c|c|}
\hline & & & \multicolumn{5}{|c|}{ Paired Differences } & \multirow{3}{*}{$\mathrm{t}$} & \multirow{3}{*}{ df } & \multirow{3}{*}{ Sig. } \\
\hline & & & \multirow[t]{2}{*}{ Mean } & \multirow{2}{*}{$\begin{array}{l}\text { Std. } \\
\text { Deviation }\end{array}$} & \multirow{2}{*}{$\begin{array}{l}\text { Std. } \\
\text { Error } \\
\text { Mean }\end{array}$} & \multicolumn{2}{|c|}{$\begin{array}{l}95 \% \text { Confidence Interval } \\
\text { of the Difference }\end{array}$} & & & \\
\hline & & & & & & Lower & Upper & & & \\
\hline \multirow{5}{*}{ Pair 1} & \multirow{4}{*}{$\begin{array}{l}\text { Pretest high VLI- } \\
\text { pretest high TCI }\end{array}$} & $\begin{array}{l}\text { Originality- } \\
\text { Originality }\end{array}$ & 3.00 & 2.11 & .38 & 3.79 & 2.20 & 7.76 & 29 & .00 \\
\hline & & $\begin{array}{l}\text { Flexibility- } \\
\text { Flexibility }\end{array}$ & .30 & 2.78 & .50 & .73 & 1.33 & .59 & 29 & .55 \\
\hline & & $\begin{array}{l}\text { Elaboration- } \\
\text { Elaboration }\end{array}$ & .60 & 1.49 & .27 & .04 & 1.15 & 2.19 & 29 & .03 \\
\hline & & $\begin{array}{l}\text { Fluency- } \\
\text { Fluency }\end{array}$ & 5.03 & 2.93 & .53 & 3.93 & 6.12 & 9.40 & 29 & .00 \\
\hline & \multirow{6}{*}{$\begin{array}{l}\text { Posttest high VLI- } \\
\text { posttest high TCI }\end{array}$} & Creativity & 15.50 & 10.90 & 2.10 & 16.05 & 16.10 & 10.20 & 29 & .01 \\
\hline \multirow{5}{*}{ Pair 2} & & $\begin{array}{l}\text { Originality- } \\
\text { Originality }\end{array}$ & 6.66 & 2.49 & .45 & 7.59 & 5.73 & 14.62 & 29 & .00 \\
\hline & & $\begin{array}{l}\text { Flexibility- } \\
\text { Flexibility }\end{array}$ & 3.86 & 2.51 & .45 & 4.80 & 2.92 & 8.42 & 29 & .00 \\
\hline & & $\begin{array}{l}\text { Elaboration- } \\
\text { Elaboration }\end{array}$ & 6.20 & 2.05 & .37 & 6.96 & 5.43 & 16.50 & 29 & .00 \\
\hline & & $\begin{array}{l}\text { Fluency- } \\
\text { Fluency }\end{array}$ & 10.93 & 4.64 & .84 & 12.66 & 9.19 & 12.89 & 29 & .00 \\
\hline & & Creativity & 25.90 & 10.98 & 209 & 32.01 & 22.78 & 17.75 & 29 & .00 \\
\hline \multirow{5}{*}{ Pair 3} & \multirow{5}{*}{$\begin{array}{l}\text { Pretest low VLI- } \\
\text { pretest low TCI }\end{array}$} & $\begin{array}{l}\text { Originality- } \\
\text { Originality }\end{array}$ & 2.033 & 3.02 & .55 & .90 & 3.16 & 3.68 & 29 & .00 \\
\hline & & $\begin{array}{l}\text { Flexibility- } \\
\text { Flexibility }\end{array}$ & 2.76 & 3.08 & .562 & 1.61 & 3.91 & 4.91 & 29 & .00 \\
\hline & & $\begin{array}{l}\text { Elaboration- } \\
\text { Elaboration }\end{array}$ & 3.30 & 2.60 & .47 & 2.32 & 4.27 & 6.94 & 29 & .00 \\
\hline & & $\begin{array}{l}\text { Fluency- } \\
\text { Fluency }\end{array}$ & 2.83 & 2.10 & .38 & 2.04 & 3.61 & 7.38 & 29 & .00 \\
\hline & & Creativity & 10.50 & 9.60 & 1.86 & 5.30 & 18.20 & 8.23 & 29 & .00 \\
\hline \multirow{5}{*}{ Pair 4} & \multirow{5}{*}{$\begin{array}{l}\text { Posttest low VLI- } \\
\text { posttest low TCI }\end{array}$} & $\begin{array}{l}\text { Originality- } \\
\text { Originality }\end{array}$ & 7.00 & 2.05 & .37 & 7.76 & 6.23 & 18.6 & 29 & .00 \\
\hline & & $\begin{array}{l}\text { Flexibility- } \\
\text { Flexibility }\end{array}$ & 7.16 & 2.71 & .49 & 8.18 & 6.15 & 14.44 & 29 & .00 \\
\hline & & $\begin{array}{l}\text { Elaboration- } \\
\text { Elaboration }\end{array}$ & 8.36 & 2.00 & .36 & 9.11 & 7.61 & 22.81 & 29 & .00 \\
\hline & & $\begin{array}{l}\text { Fluency- } \\
\text { Fluency }\end{array}$ & 15.93 & 4.54 & .83 & 17.63 & 14.23 & 19.18 & 29 & .00 \\
\hline & & Creativity & 37.49 & 10.97 & 2.05 & 40.89 & 33.86 & 23.12 & 29 & .00 \\
\hline
\end{tabular}

As the second research question was concerned with the difference between VLI and TCI groups in different proficiency levels, the results of the four sub- questions show both high and low VLI groups had a better performance than both high and low TCI groups in both pretest and posttest, so the results rejected the second null hypothesis. The major difference was related to the performance of low VLI in pre- and post-test, which indicates that the application of VLI had a real positive effect on this group.

So, virtual environment is considered desirable and it is assumed that it can positively affect the effectiveness of education. VLI environment can reinforce concepts learnt and provide the ability for on-demand learning.

\subsection{Evaluate the Attitudes of Learners Regarding to Different Learning Instruction}

At the end of posttest to gather the information of attitude from both VLI and TCI groups from selected sample for this study, the investigator used the tool, Attitude Scale of Creative Teaching developed by Dundee. 
Table 11 shows the mean score of VLI groups in attitude was $100.74(\mathrm{SD}=30.71)$ ranging from 45 to 159 .

Table 11. Attitude results in VLI group

\begin{tabular}{lllllll}
\hline & Groups & N & Min. & Max. & Mean & Std. Deviation \\
\hline Learners' Perception of Learning (SPoL) & VLI & 60 & .00 & 8.00 & 5.80 & 2.44 \\
Learners' Perception of Teaching (SPoT) & VLI & 60 & 10.00 & 43.00 & 26.11 & 9.28 \\
Learners' Academic Self-Perception (SASP) & VLI & 60 & 5.00 & 32.00 & 19.98 & 5.94 \\
Learners' Perception of Atmosphere (SPoA) & VLI & 60 & 20.00 & 48.00 & 35.40 & 7.69 \\
Learners' Social Self-Perception(SSSP) & VLI & 60 & 10.00 & 28.00 & 18.45 & 4.36 \\
General Attitude & VLI & 60 & 45 & 159 & 100.74 & 30.71 \\
Learners' Perception of Learning (SPoL) & TCI & 60 & .00 & 8.00 & 3.78 & 2.31 \\
Learners' Perception of Teaching (SPoT) & TCI & 60 & 3.00 & 50.00 & 26.65 & 11.01 \\
Learners' Academic Self-Perception (SASP) & TCI & 60 & 10.00 & 38.00 & 22.16 & 7.33 \\
Learners' Perception of Atmosphere (SPoA) & TCI & 60 & .00 & 31.00 & 15.05 & 7.90 \\
Learners' Social Self-Perception (SSSP) & TCI & 60 & .00 & 25.00 & 9.91 & 7.16 \\
General Attitude & TCI & 60 & 13 & 152 & 73.55 & 34.71 \\
\hline
\end{tabular}

Based on Table 11, the student in VLI group had higher satisfaction from learning atmosphere with mean score of 35.40 ( $\mathrm{SD}=7.69)$. The student in TCI group had higher satisfaction from perception of teaching with mean score of $26.65(\mathrm{SD}=11.01)$. As Table 11 shows, there is a significance difference between two group $(\mathrm{p}<0.05)$. the attitude of VLI group was better than TCI group. So, If the learners find learning instruction attractive, leading to higher degrees of satisfaction (Dundee, 1997), and Degrees of satisfaction had been widely used to evaluate the effectiveness of learning in different learning situation. Table 12 shows a paired sample T-tests for every pair of groups.

Table 12. Paired samples t-test for both groups in attitude

\begin{tabular}{|c|c|c|c|c|c|c|c|c|}
\hline & \multicolumn{5}{|c|}{ Paired Differences } & \multirow{3}{*}{$\mathrm{t}$} & \multirow{3}{*}{ df } & \multirow{3}{*}{ Sig. } \\
\hline & \multirow[t]{2}{*}{ Mean } & \multirow{2}{*}{$\begin{array}{l}\text { Std. } \\
\text { Deviation }\end{array}$} & \multirow{2}{*}{$\begin{array}{l}\text { Std. } \\
\text { Error } \\
\text { Mean }\end{array}$} & \multicolumn{2}{|c|}{$\begin{array}{l}95 \% \text { Confidence Interval } \\
\text { of the Difference }\end{array}$} & & & \\
\hline & & & & Lower & Upper & & & \\
\hline SpoLVl-SpoL TCI & 2.01 & 3.10 & .40 & 1.21 & 2.81 & 5.03 & 59 & .00 \\
\hline SPoT VLI-SPoT TCI & .53 & 10.53 & 1.35 & 3.25 & 2.18 & .39 & 59 & .69 \\
\hline SASP VLI-SASP TCI & 2.18 & 7.78 & 1.00 & 4.19 & .17 & 2.17 & 59 & .03 \\
\hline SPoA VLI-SPoA TCI & 20.35 & 11.72 & 1.51 & 17.32 & 23.37 & 13.44 & 59 & .00 \\
\hline SSSP VLI-SSSP TCI & 8.53 & 8.82 & 1.13 & 6.25 & 10.81 & 7.48 & 59 & .00 \\
\hline General attitude & 27.19 & 40.80 & 4.39 & 31092 & 38.32 & 14.39 & 59 & .01 \\
\hline
\end{tabular}

So the answer to the third question is positive and the third hypothesis is rejected. The higher degree of satisfaction was shown by VLI learners and their ability to overcome different situations. The results shownthe positive effect of virtual instruction and feedback during fourteen treatment sessions for VLI and TCI groups. According to the results of Table 12, the learning atmosphere more affected creativity of girl learners and also provideda degree of freedom and openness to experience. This means learners' perception of teaching have an important impact on Creativity of learners as it can provide an appropriate context for fostering the creativity of these learners.

\section{Discussion}

The goal of this research was to explore the effect of VLI and TCI on creative thinking among female EFLlearners. This study was designed to find answers to three research questions. The first one was to see the differences between VLI and TCI groups on creative thinking by Iranian EFL learners. The answer to the first question of the present study was positive as VLI group differed significantly from TCI group from pretest to 
posttest. Also, VLI had a positive effect on creative thinking in posttest, even for those with lower scores in pretest. It was observed that the use of computers and Internet in the process of learning new information is one of the areas that have received the attention of many participants. The findings of this study about VLI were in line with the results of the previous studies in the literature for example, Cotton (2003), who has suggested that the repetitive nature of input through internet assists learners in understanding subjects. The findings are also in line with the findings of Maslow (1991) whose research findings revealed positive and consistent patterns of effectiveness of technology when learners were engaged in teaching environments. However, not much study has been found about the application of VLI and TCI on creative thinking. Prensky (2000) emphasized that for learners, world without computers, digital media or the internet is meaningless.

The second question was to see the effect of proficiency level of VLI and TCI groups on creative thinking by female EFL learners in different proficiency levels. The answer to this question was positive because statistically significant difference was found on the performance of VLI and TCI in their high and low groups from pretest to posttest and the reason was the appropriate types of satisfaction which VLI group received. Halvorsen (2005) believed that using creative thinking can actually make ESL/EFL classes better by making the activities more interesting for the learners and also giving the class a more meaningful and cohesive environment. The findings of senge (2006) could all be considered generally positive toward this study with regard toapplication of VLI in different proficiency levels.

The third research question of this study to be under investigation was to identify the attitudes of learners between VLI and TCI regarding to different learning instruction among female EFL learners. The result of the present study was in line with the studies of Asmus (2001) who concluded that cognitive and personality characteristics had mutual impact and individual's attitudes had a result on his presentation. Cotton (2001) whose research findings revealed that the use of VLI leads to more positive student attitudes than the use of conventional instruction.

Generally, from the data in the current study, it could be stated that there was significant difference between attitudes of female EFL learners in VLI and TCI groups. According tofindings of this study, it was statistically proved that the virtual learning instruction can be a very importance for providing input. So, Computers and language learning are closely inter-related andintegration of both can help learners to organize, process data and modify further input accordingly.

\section{Conclusion}

The purpose of this study is to investigate the effects of VLI and TCI on creative thinking of female EFL learners. The participants' pre- and post-test results proved that when instruction is mediated to the participants appropriately, it helps to improve learning and also increase creative thinking. The participants were able to learn the lessons on different situations and take a step further and apply them to the posttest. With regard to the findings of the present research with VLI and TCI groups, the following conclusions were reached:

The analysis of the results highlighted the advantages of application of VLI over TCI in creative thinking performance of learners. The first advantage is the development of learners' independent performance to solve problems and their abilities asresult in which helps them in future.

The second advantage is the integration of instruction and assessment which provides opportunities for learners development not only from past to present, but better integration for non-full-time particularly in continuing education.

The third advantage is that the VLI group received the instruction that not only focused on temporary effects of learning, but it also tried to make permanent changes in the attitudes of learners which lead into their development. As Oxford (2006) has suggested using authentic tasks can increase the learner's motivation for taking part in classroom activities and participate in different task-based activities.

In this research it was concluded that VLI group brought about changes from pretest to posttest because they had positive attitudes. These attitudes led to better performance. However, the changes in TCI group were not very significant because they did not show positive attitude to learning compared with the TCI groups. Moreover, the findings of the present study showed that proficiency level of learners in different VLI and TCI groups affected their creative thinking.

This study also indicated that when the same information and instruction were given to learners in VLI and TCI groups, they tended to use a variety of creative thinking in posttest. This finding confirms the practical value of VLI, because it provides in-depth information about the different thinking of the learners. 


\section{References}

Alagozlu, N. (2007). Critical Thinking and Voice in EFL Writing. Asian EFL Journal, 9(3), 118-136.

Albertson, L. R., \& Billingsley, F. F. (2002). Improving Young Writers' Planning and Reviewing Skills while Story-Writing (pp. 24-28). Paper Presented at the Annual Meeting of the American Educational Research Association.

Allport, G. W., Vernon, P. E., \& Lindzey, G. (1951). Study of values: Manual of directions. Boston: Houghton-Mifflin.

Alreck, T. L., \& Settle, B. R. (1995). The survey research handbook. Chicago: Irwin Inc.

Amabile, T. M. (1983). The social psychology of creativity: A componential conceptualization. Journal of Personality and Social Psychology, 45, 357-376.

Andreason, N. C., \& Cantor, A. (1974). The creative writer: Psychiatric symptoms and family history. Comprehensive Psychiatry, 15, 123-131.

Banaji, S., \& Burn, A. (2006). The Rhetoric's of Creativity: A review of the literature. London: Arts Council of England.

Barron, F. (1958). The needs for order and disorder as motives in creative activity. In C. W. Taylor (Ed.), the 1957 research conference on the identification of creative scientific talent (pp. 119-128). Salt Lake City: University of Utah Press.

Barron, F. (1961). Creative vision and expression in writing and painting. In Conference on creative person (pp. 1-19). Berkeley: Institute of Personality Assessment and Research, University of California.

Billmeyer, R. (2003). Strategies to engage the mind of the learner: Building Strategic Learners. Omaha: Dayspring, 10.

Bloom, B. S. (1956). The classification of educational goals, handbook cognitive domain. New York: Gilford.

Collis, B., Vingerhoets, J., \& Moonen, J. (1997). Flexibility as a key construct in European training: Experiences from the telescopic project. British journal of educational technology, 28(3), 217.

Cotton, K. (2001). Teaching thinking skills. Northwest Regional Educational Laboratory. Retrieved from http://www.nwrel.org/scpd/sirs/6/cu11.htm

Cotton, K. (2003). Principals and Student Achievement: What the research says. Alexandria, VA: Association for Supervision and Curriculum Development.

Davis, G. A. (2006). Gifted children and gifted education: A handbook for teachers and parents. Scottsdale, AZ: Great Potential Press.

Dewey, J. D. (1999). How we think, a restatement of the relation of reflective thinking to the educative process. Boston: D. C. Health.

Dimoliatis, E. (2010). Validation of the Greek translation of the Dundee ready education environment measure (DREEM). Education for Health 10 (online), 348.

Fleith, D. (2000). Teacher and student perceptions of creativity in the classroom environment.

Gardner, R., \& Lambert, W. (1985). Attitudes and Motivation in Second Language Learning. Rowley, Massachussets: Newbury House Publishers.

Gergen, K. J. (1971). The concept of self. New York: Holt, Rinehart and Winston.

Getzeis, J. W., \& Csikszentmihalyi, M. (1996). The creative vision: Longitudinal study of problem finding in art. New York: Wiley.

Ghiselin, B. (1952). The creative process. Berkeley. California University Press.

Gilford, J. (1976). Intellectual factors in productive thinking. In R. Mooney, \& T. Rayik (Eds.), Explorations in creativity. New York: Harper \& Row.

Gilford, J. P. (1950). Creativity. American Psychologist, 14, 469-479.

Gokhale, A. A. (1996). Effectiveness of computer simulation for enhancing higher order thinking. Journal of Industrial Teacher Education, 33(4), 36-46.

Halvorsen, T. et al. (2005). On the differences between public and private sector innovation. Oslo, Norway. 
Harding, R. (1965). An anatomy of inspiration. New York: Barnes and Noble.

Harkow, R. M. (1996). Increasing creative thinking skills in second and third grade gifted students using imagery, computers, and creative problem solving. NOVA Southeastern University.

Hayward, P. (2007). Vanessa Quai-Linking Vanuatu to the World: A Tribute her First Decade in Music (1997-2007). Port Vila: Vanessa Quai Music Foundation.

Hudson, L. (1975). Human beings: The psychology of human experience. New York: Anchor.

Kroeber, A. L. (1944). Configurations of culture growth. Berkeley: University of California Press.

Larson, R. (2002). Globalization, societal change, and new technologies: What they mean for the future of adolescence. Journal of Research on Adolescence, 12(1), 1-30.

Maleki, H. (2000). Curriculum (action) (p. 296). Tehran: School Publishing.

Mayer, D. (2007). Discovering your authentic leadership. Harvard Business Review, 85(2), 129-138.

Paul, R., Elder, L., \& Bartell, T. (2003). Study of 38 public universities and 28 private universities to determine faculty emphasis on creative thinking in instruction. Retrieved from http://www.criticalthinking.org

Prensky, M. (2000). Digital game-based learning. New York: McGraw-Hill.

Sauer, E. (2005). Emotions in Leadership. Leading a Dramatic Ensemble. Tampere, University of Tampere Press.

Savage, E., \& Sterry, L. (1990). A conceptual framework for technology education (p. 15). Reston, VA: International Technology Education Association.

Szendeffy, J. (2005). A Practical Guide to Using Computers in Language Teaching. Ann Arbor: University of Michigan Press.

Taylor, I. A. (2007). The nature of the creative process. In P. Smith (Ed.), Creativity: An examination of the creative process (pp. 51-82). New York: Hastings House Publishers.

Thackeray, W. M. (1899). The works of W. M. Thackeray (Vol. 12). London: John Murray.

Till, H. (2004). Identifying the perceived weaknesses of a new curriculum by means of the Dundee Ready Education Environment Measure (DREEM) Inventory. Medical Teacher, 26(1), 39-45.

Torrance, E. P. (1965). Creativity. In F. W. Hubbard (Ed.), what research says to the teacher? Washington, DC: Department of Classroom Teachers American Educational Research Association of the National Education Association.

Werner, H. (1948). Comparative psychology of mental development. New York: International Universities Press.

\section{Copyrights}

Copyright for this article is retained by the author(s), with first publication rights granted to the journal.

This is an open-access article distributed under the terms and conditions of the Creative Commons Attribution license (http://creativecommons.org/licenses/by/3.0/). 